\title{
Utopiske Europa (UE)
}

\author{
MiKaEL JALVING
}

"Jeg tvivler, altså er jeg europæer", skrev Per Stig Møller for nogle år siden, "thi lige fra grækerne finder vi ved siden af overmodet mismodet. Ved siden af selvtilliden mistilliden. Det er denne tvivl, der forandrer verden". Betragtningen er ikke uden filosofisk og sproglig prægnans, men glemmer, at Europa som begreb er af langtnyere dato. Ja, det klinger sågar politisk og geografisk meningsløst helt op gennem middelalderen for endelig at fødes i 1500-tallet. Hvis grækerne tvivlede, var det altså fordi, de var grækere eller måske endda blot athenere eller spartanere. Efter romerrigets fald var det derimod først og fremmest kristenheden, der definerede den europæiske mosaik, hvad den dog ikke blev "europæisk" af, og dertil den sydfrakommende islamiske tro, som øvede indflydelse på en tøvende indre samling på kontinentet, men begrebet Europa fandtes ikke i nogen videre betydning. Det må nemlig knyttes til sækulariseringen for at få mening og fylde.

Det vil være dette essays påstand, at Europa, som vi er kommet til at kende hende, dvs. gennem historien, slet ikke behøves at tænkes eller forestilles som drøm, da Europa i sin kerne er en drøm. Kernen rummer en politisk utopi. Forudsætningen for at hævde således gives ved det interessante sammenfald mellem den mentale opdagelse af Europa og utopiens fødsel som litterær-politisk genre - her tænker jeg på Thomas Mores Utopia (1516) over alle andre. Hovedproblemet ved denne påstand kan siges meget kort: Platon og dennes Staten, der jo som bekendt er blevet læst konkret og socialt som den første samfundsutopi overhovedet. Jeg skal komme ind på, hvorfor min påstand ikke rammes af dette forhold. Et andet problem gives ved mit syn på 
middelalderen som lidet innovativ i politisk-kulturel henseende, hvor man kan forvente at se Michael Nordberg eller Uffe Østergård komme rendende med deres dynamiske middelalder overfor hvilken reaktion, jeg ikke har andet forsvar end et erklæret udgàngspunkt i renæssancen, som for mig at se stadig må regnes for omdrejningspunktet for den moderne verden. Mit budskab kan derfor $i$ en aktuel sammenhæng anvendes til samme formål som det indledende citat til trods for den historiske forskydning - just som en påpegning af, at når dagens tunge realisme i samfundstænkningen erklærer, at virkeligheden varer længere end drømmen, så udvaskes forståelsen for, at Europas kulturelle særkende lige siden renæssancen har været evnen til at ændre tingenes tilstand, et særkende, der efter min smag aldrig bør tabes. Thi først foruden denne kvalitet i udsynet skal vi få virkeligheden at føle i form af fantasiløshed og indavl på alle planer.

Fremhævelsen af en særlig europæisk rastløshed synes ikke synderlig original. Man har med Goethe talt om Europas „faustiske sjæl ", dvs. om vor til stadighed higende ånd, der betaler for tekniske og eventuelle erkendelsesmæssige fremskridt med den straf aldrig at kunne finde hvile. Videre, højere, længere. Men vi skal i det følgende gribe tilbage til Mores skrift for at sammenligne det bagud med Platons Staten og fremad med Karl Marx' arbejder om utopi og revolution, og på denne led forsøge at lodd̄e rastløshedens dimensioner. Som Melvin J. Lasky skrev i sit murstenstunge, indsigtsmættede og samtidig uklare, men for tanken befordrende værk Utopia and Revolution (1976), så er alle utopister revolutionære, mens ikke alle revolutionære er utopister (dette er ikke helt korrekt, idet der også kan være tale om relative utopier, evolutionære snarere end revolutionære, men det vælger vi at se bort fra her). Helt udenfor denne diskurs opererer den traditionelle politiske konservatisme, der i strikt forstand interessant nok er yngre end utopismen, og som oplever denne som mareridt på mareridt. Utopien forstås i dette lys som noget, hvis virkeliggørelse kun udgør en altfor nærværende trussel. Arketypisk for denne "sene" konservatisme er Edmund Burke (1729-97). Forinden er gået, hvad Lasky kalder 1600-tallets „engelske ideologi", en pragmatisme i sociale anliggender influeret af 
John Locke og David Humes tanker, som indirekte vaccinerede englænderne imod revolution.

\section{I}

"Utopi“ er afledt af græsk og betyder både intetsteds (outopia) og det gode sted (eutopia). Man har skændtes om, hvorvidt More, der introducerede metaforen var oprigtig i beskrivelsen af det gode sted, eller om han omvendt ønskede at udstille det satirisk som et ikke-sted. Hvis værket er det sidste, er det et dårligt sådant, idet man som læser snarere mærker en vis overtalelseseffekt, og kigger man blot et øjeblik på Mores biografi, synes den tolkning, der også kommer til udtryk i et tilføjet versmål, at Utopia burde have heddet Eutopia, meget mere plausibel.

Mores fiktion er behæftet med den finte, at historien fortælles til More selv og hans faktiske ven Peter Giles i Mores baghave; dette greb inkluderer en grad af realisme, som den læsende samtid skal have taget for pålydende. For at gardere sig imod den engelske konges repressalier afsluttede More da beretningen med en realkommentar, der skulle lægge lidt afstand til, hvad han lige havde "hørt". Beretningens „kilde“ er sømanden Raphael Hythlodeus (ordret "ekspert i vrøvl"), der på en af søfareren Amerigo Vespuccis ekspeditioner opnår tilladelse til at forblive i den nye verden og ved egen hjælp finder frem til øen Utopia, hvor alt fungerer så anderledes end hjemme i det monarkiske England (Europa). Referencen til Amerigo er naturligvis ligeledes fiktiv, men tilførte fortællingen genkendelighed. Det samme gælder den omstændighed, at Hythlodeus i første bog (af to) refererer en diskussion om aktuelle samfundsspørgsmål, han har haft i ærkebiskop og kardinal John Mortons hus, hvor More endvidere skal have været opvokset. Under denne diskussion, der viser Hythlodeus som en ærlig utopist, møder vi den krans af eftersnakkere, enhver religiøs eller politisk leder var omringet af under et styre som det engelske på denne tid. Denne observation sløres imidlertid af den første og siden autoritative oversættelse af værket fra latin til engelsk, udført i 1551 af Ralph Robinson. Som Richard Marius skriver i sin note om oversættelsen i serien Everymans udgave (1994), så var Robinsons største fejl, at han 
konverterede værkets republikanske utopi til en monarkisk utopi og anvendte betegnelsen „Kong Utopus“ om Utopias øverste leder. Mores latinske version derimod, beskrev en alternativ statsform til den gængse ved at betone det folkelige på bekostning af det royale og adelige, hvad bliver tydeligst $i$ værkets anden bog.

Før vi når dertil skal vi imidlertid gøre et kort ophold ved værkets klassiske dilemma. Monarkiets problem, hævder Hythlodeus, er at dets regenter og talsmænd af egoistiske grunde altid finder legitimation i fortiden derved, at de anser det som yderst farligt, hvis mennesket på noget punkt fordrer at være klogere end sine forfædre. Dette tømmer selvsagt utopien for potentiale. Hythlodeus afviser følgelig muligheden af at tjene monarkiet via rådgivning, da den kloge rådgiver (filosoffen) med sikkerhed vil tale før døve øren. Heroverfor indvender More, dvs. som figur mere end som sig selv, at filosoffen må tilpasse sig de rådende forhold, den virkelige verden, og ej søge uorden. Prisen for ikke at ville nøjes med det muliges frugt, er nemlig, som "More" siger, at staten lades i stikken, hvilket det er filosoffens ansvar at undgå. Dilemmaet formuleres i samme Mores spørgsmål: „For whereas your Plato judgeth that wealpublics shall by this means attain perfect felicity, either if philosophers be kings, or else if kings give themselves to the study of philosophy, how far, I pray you, shall commonwealths then be from this felicity, if philosophers will vouchsafe to instruct kings with their good counsel?" (p.39). Men Hythlodeus besidder netop intet svar, thi for ham er monarkiet ingen farbar vej mod menneskelig lykke. Dertil rækker kun utopien.

I værkets anden bog berettes om utopisternes $\varnothing$ med hovedbyen Amaurote (ordret "tågebyen") ved floden Anyders bredder, hvilket unægtelig leder tankerne i retning af London. På øen er landbruget det primære erhverv, der leverer fødevarer til byerne, hvor man ligesom udenfor er organiseret kooperativt i store husholdninger. Disse lægger stærkere bånd på hver enkelt end familierne gør: Der arbejdes seks timer dagligt, den øvrige tid kan gå til to bestemte og opdragende spil eller åndelig beskæftigelse, der vurderes som livets sande gerning. I det hele taget her- 
sker en asketisk og kollektiv ånd. Ejedomretten er fælles. Offentlighedskulturen synes fuldstændig, og den stræben efter menneskelig perfektionalitet, styret tilsigter, virker i Hythlodeus' referat succesfuld. Den republikanske statsform kommer klarest til udtryk gennem en grundlæggende demokratisk aspiration, idet der i Utopia afholdes valg, og det endda hemmelige valg, til de forskellige råd $\mathrm{i}$ byerne, på landet og til præsteembederne, hvilket målt med tidens alen udgør et drastisk alternativ. Således hedder det, at flertallet ikke blot er den største, men tillige bedste part af menneskene, hvad tør kaldes et synspunkt, som i sin radikalitet betaler tribut til demokratiet. Der gives desuden religionsfrihed, men også dødsstraf og slaveri. Der findes hverken militærpligt eller advokater, ligesom pengesystemet er afviklet, men alle skal gå ens klædt, og må søge om tilladelse forud for selv små rejser. Men hvorfor skulle man også rejse rundt på øen, når den i alt væsentligt er så ensartet? Det overflødige spørgsmål symboliserer for Hythlodeus en dyd, tanken om denne ædle lighed.

More tager som sagt sine forbehold mod slutningen. At de er taktiske, understreges af den afsluttende ironi, hvormed More i parentes bemærker, at Utopia betyder afskaffelse af ",all nobility, magnificence, worship, honour, and majesty" (p.135). Klarere kan det vist ikke siges. Parentes slut.

\section{II}

More var tydeligvis bekendt med Platon, hvem både figuren More og Hythlodeus henviser til. Platons klassiske tekster blev da også netop genopdaget på denne tid sammen med antikken som sådan. Men læser man Staten som et socialt og politisk manifest - og ikke som et metaforisk og i grunden apolitisk værk møntet på hver enkelt som sin egen enhed, som sin egen stat adskiller dette sig fundamentalt fra Mores samfundsutopi, og grundfarven i beskrivelsen af denne forskel bliver hævdelsen af, at Platons utopi er antik, mens Mores er moderne, dvs. europæisk, skønt Mores Utopia indeholder et traditionelt antikt fænomen, nemlig formaliseret slaveri. 
De to motiver, som ligger til grund for forfatterne, er kort sagt væsensforskellige. More ledes som nævnt af en demokratisk og egalitær aspiration; Platon, dvs. stadig i den socialt-politiske fortolkning, ledes af en hierakisk eller konserverende aspiration. Dertil kommer det historiske fokus for hver af de to modeller. Hvad Platon har $\mathbf{i}$ tankerne er polis, bystaten, et stykke rendyrket kultur, et bytorv som mikrokosmos med begrænset horisont. Mores længsler næres ved tanken om en statsform, der kan blive Europas med både land og by inkorporeret, utvivlsomt længsler forstærket af samtidens revolutionerende opdagelse af klodens geografi. Mores horisont er altså global til trods for, at Utopia synes at være en $\varnothing$, dvs. by.

Den eneste lighed modellerne imellem er slaveriet. Platon regner det som en forudsætning for statens beståen, More tøver med at kvalificere sin begrundelse, idet slaveriet tænkes at virke generelt opdragende på slaverne såvel som på de borgere, der måtte overveje at forsynde sig imod statens regulativer. Samtidig sættes slaverne til at aflive dyr, hvad ellers risikere at korrumpere eller forrå gode samfundsmedlemmer. Mores slaveri fremstår mest af alt som en rest fra antikken, måske med den hensigt at gøre utopien mere eksotisk. Jeg vælger derfor i det resterende at forbigå denne lighed.

I den konkrete læsning af Platon gives den optimale socialstruktur med tredelingen mellem filosofikongerne øverst, producenterne nederst og de militære hjælpegrupper i midten. Om kongerne ret beset er filosoffer eller om det er filosofferne, der er konger, skulle være mindre vigtigt end det forhold, at filosoffen bidrager direkte til utopiens realisation. Mores afvisning heraf er allerede omtalt, ihvert fald når det gælder monarkiet, hvis vejleder ingen bør være. Iagttagelsen leder os til den pointe, at Mores samfundsideal i modsætning til Platons effektueres af den glade amatør i politik, erhverv og filosofi, af den velmenende og ligesindede demokrat. For Platon derimod var kun én samfundsform ringere end demokratiet, nemlig tyranniet, der dér regnes for en vanartet version af det gode, professionelle styre med én leder. Om den demokratiske dilettant hedder det i Staten: „På den måde lever han så fra dag til dag, idet han tilfredsstiller en 
eller anden tilfældig grille: en dag tilbringer han med drik og svir og fløjtespil, den næste er han på vandkur og streng diæt; snart hærder han sig ved idræt, og snart falder han hen i dorskhed og sløvhed, for så en anden dag sågar at give sig ud for filosof! $\mathrm{Nu}$ og da går han ind i politik, springer op og taler for og søger at gennemføre en eller anden plan. Så fatter han pludselig beundring for militærlivet og vil drive det til noget stort deri, en anden gang vil han være storkøbmand - kort sagt, hans liv hvis princip er mangel på principper bliver tilfældigt og vilkårligt, omend han selv kalder det en yderst tiltalende og behagelig fri mands tilværelse, som han holder fast på gennem årene" (8.561d). Citatet kontrasteres af Mores Utopia, hvori menneskene ikke gør ét til perfektion, men cirkulerer og roterer indenfor det egalitære fællesskabs grænser, som alligevel virker trange for en moderne læser.

Krishan Kumar har i studierne Utopia and Anti-Utopia in Modern Times (1987) og Utopianism (1991) forsøgt at definere forskellen på More og Platons utopi ved at modstille Mores såkaldte "litterære metode" med sidstnævntes "deduktive teori", som iøvrigt også skulle være Marx' metode. Platon og Marx deducerer, More illustrerer. Snittet mellem de to eller tre bør efter min mening lægges anderledes. Som vist i del I støder man så sandelig på reflektion og forudgående præmisser under læsningen af Utopia, som altså nok kan skattes lig et stykke litteratur, men endvidere behandler det klassiske spørgsmål om den vises rådgivning eller eksklusivitet, samt funderes på ideen om menneskets perfektionalitet og troen på åndeligt arbejde som det sandeste. Desuden underforstås en social konstruktion uden privat ejendomsret og et bredt udfoldet demokrati, altså igen forud-gående og grundlags-givende værdier, der meget dårligt lader sig reducere til litterære kneb. Forskellen er derfor ikke, som Kumar anfører, en forskel i „form" eller en klassifikation udfra graden af "realisme" i Mores og Platons utopier, men snarere en forskel afhængig af det indhold, de hver især giver formen. Kumar har selvfølgelig ret, hvis han - som han hælder mod i det sidste værk (p.40) men siden forlader! (p.48-50,64,72) - mener at læse Platon metaforisk på individplan, hvor mennesket vel at mærke først 
bliver menneske ved at forholde sig moralsk til spørgsmålet om det gode liv, og ikke til staten og al dens væsen. For så handler Staten jo slet ikke om, hvordan den bedste stat etableres, men om, hvorledes man bliver et godt menneske, hvilket fører os bort fra det kollektive. Også denne mulighed må jeg forbigå i tavshed.

Kumars formkriterier bliver desto mere problematiske, når blikket falder på Marx, der afskyede utopier og så langt foretrak revolutionen. Marx skrev kun yderst lidt og spredt om, hvad revolutionen egentlig vil bringe, skønt det er ingen utopi, så meget ved vi. Et slægtsskab med Mores forhåbning er dog den demokratiske aspiration og drømmen om det glade allround-menneske, hvilket vi finder i Marx' hyppigt citerede formulering om at kunne være jæger om morgenen, fisker om eftermiddagen, hyrde om aftenen og øve kritik efter aftensmaden uden at blive nogen af delene. I det kommende samfund skal ingen leve indenfor "en begrænset virkekreds", men nødvendigvis gå fra det borgerlige samfunds fremmedgørelse til kollektivets frigørelse. Mores ø-samfund afviger imidlertid fra ovennævnte ved at være et folkestyre uden økonomisk og videnskabelig vækst, det er et statisk rige, hvis ophav ligger på den anden side af de videnskabelige revolutioner hos Francis Bacon og andres opdagelser et århundrede senere. Marx beskuede dette tidehverv fra vor side og overtog fremskridtstroen for at lægge afstand til, hvad han kalder den utopiske socialisme, hvis mål han foragter som drømmeri og tomme ønsker. Denne socialisme mangler netop hele den historiske materialisme. „Står det menneskene frit at vælge den ene eller den anden samfundsform ", spørger Marxi anledning af P.-J. Proudhons skrift af 1846 og afviser blankt: „Tag et bestemt trin i udviklingen af menneskenes produktivkræfter, og De vil have en bestemt form for handel og konsumption. Tag bestemte grader i udviklingen af produktionen, handelen, konsumptionen, og De vil have en bestemt form for samfundsorden, en bestemt organisation af familien, stænderne eller klasserne, kort sagt et tilsvarende borgerligt samfund. Tag et sådant (...), og De vil have en tilsvarende politisk stat, som ikke er andet end det borgerlige samfunds officielle udtryk. Det er det, Hr. Proudhon aldrig vil komme til at forstå" (cit. eft. bilag til Filosofiens elendig- 
hed (1847), Kbh. 1973, p.130). Den ønskværdige fremtid afhænger af, om man forstår historiens gang videnskabeligt, dvs. ser hvad den bærer i sig. Uden denne forståelse er alting omsonst, dvs. foruden mister arbejderklassen muligheden for at forberede sig på det, der kommer og må komme. Marx' pointe er altså, at selvom historien går sin uafvendelige gang, må jorden prepareres med videnskab, så grundlaget for "samlet aktion", der ifølge Det kommunistiske partis manifest (1848) „er en af de første betingelser for proletariatets befrielse" , kan defineres:

Man opfatter almindeligvis denne optik som en slags positiv udviklingslære under indflydelse af Darwins naturteori, men bemærker måske sjældnere den tragisk-alvorlige tone, der griber Marx ved omtalen af revolutionens umiddelbare omkostninger. Revolutionen er en overgangstid fuld af vanskeligheder, idet det gamle styre aldeles må ætses væk, førend det nye kan opstå. Prisen hedder vold, ondskab, blod, terror, disciplin og enhed, men alene med ondt skal ondt fordrives. Udsigterne er således mere dystre end normalt antaget, hvad fører benævnte Lasky til at notere: „Few spokesmen for a new heaven and a new earth ever kept themselves so systematically free from images of paradise and utopia" (p.39). Med Marx' ungdomsord hedder det fra Økonomiske og filosofiske manuskripter (1844), at „kommunismen er den nærmeste fremtids nødvendige skikkelse og dens energiske princip, men kommunismen som sådan er ikke den menneskelige udviklings mål, ikke det menneskelige samfunds sande skikkelse", det kommer sidenhen, og man anfægtes af det lange perspektiv, hvormed først et senere trin i kommunismen, dens såkaldt ,tredje fase". indfrier målet. Marx var i det hele taget realist om en hals, hvad overrasker en førstegangslæser som undertegnede, der gerne finder konsultation i Villy Sørensens bemærkning om, at som Marx analyserer vejen igennem den borgerlige kapitalisme, tabes udgangspunktet og endemålet (friheden) af syne.

Der er hos Marx ikke meget at varme hænderne ved, som der er det hos More og Platon. Vekslingen af utopi til videnskab ligner ikke nogen god forretning. Marx' fremtidssamfund skal findes som brudstykker kastet hid og did i den samlede produktion. 
I Bottomore \& Rubels udvalg (1963) fylder de karakteristisk nok omkring en tiendedel. Den positive kerne ligger måske i Marx' antropologi, hvis tanke er, at "mennesket" i sin hidtidige historie aldrig har eksisteret i nogen "ren form ", og under den borgerlige kapitalisme er spaltet $i$ en formelt set fri statsborger og en reelt set selvisk og ufri samfundsborger. Spaltningen fremmedgør mennesket fra sin enhed med naturen og løses kun, hvis mennesket forstås som et ",samfundsmenneske ", og med andre ord anskues i sin sociale kontekst, hvilket igen vil sige i relation til sin klasse. Her består en positiv kerne i Marx' fremtidssamfund, der ellers synes så pauvert præciseret taget det volumniøse tekstkorpus $\mathrm{i}$ betragtning. Manifestet er vel den mindst ringe vejviser. Afskaffelsen af den private ejendomsret repræsenterer krumtappen for en "større, rigere _og bedre“ tilværelse hinsides det kompakte og stadigt voksende flertals blotte overlevelse under det gældende herredømme. En resolut magtcentralisering i "statens hænder" er forudsætningen for "en sammenslutning, hvor hver enkelts fri udvikling er betingelsen for alles fri udvikling", hvilket først giver mening med tanke på Marx' særlige antropologi, som netop sørger for, at individ og kollektiv går op i en højere enhed efter ophævelsen af klassemodsætningen, der samtidig er en ophævelse af den politiske magt, dvs. staten som sådan.

Dette syn på menneske overfor det fælles reflekterer en magtopfattelse, der går fra at være polær og antagonistisk indtil punktet, hvor revolutionen er fuldbragt - for derefter at blive holistisk. Dermed menes, at revolutionen indvarsler enheden mellem individ og stat, den enhed, allerede Jean-Jacques Rousseaus "samfundspagt " var det første forsøg på at konstruere, og som gør begreber som magtdeling og magtbalance til overflødige levn fra den borgerlige epoke og ditto teori, hvis barn istedet blev den triangulære magtopfattelse. Heri skelnes mellem faktorerne indi$\mathrm{vid} /$ familie, stat og et mellemliggende lag af frivillige sammenslutninger, derunder liberale erhverv, diverse institutioner, fagforeninger, politiske partier m.v. Pointen er dels, at faktorerne ideelt set holder hinanden i skak, hvad den holistiske magtopfattelse afviser som værende illusorisk i praksis og dels, at denne efterstræbte ligevægtstilstand er betinget af en overbevisning om 
menneskets principielle imperfektionalitet, hvad jo strider med overbevisningen om det modsatte hos Marx, More og Platon (ihvert fald ang. filosoffen). At More og Platon dermed skulle forfægte en holistisk magtopfattelse, vil det dog være forkert at sige. More tillader modsat Marx som bekendt frie, dvs. hemmelige afstemninger, som ikke nødvendigvis garanterer stabilitet og enhed, og jo i sig selv udgør en pluralisme. Og Platon læst i konkret forstand opererer med tre adskilte stænder eller samfundsklasser med divergerende funktioner til skabelse af et specialiststyre. Den overordnede styring tager lederne sig af; værnerne udretter deres på et praktisk plan, og produktionen tilvejebringes af den erhvervsdrivende stand. Hvis den borgerlige teoris modstilling af individ kontra stat virker irrelevant hos Platon, så er den imidlertid ikke ganske fraværende. Producenterne behøver strengt taget ikke ville det samme som statens øvrige medlemmer. Endvidere står den specialisering, Platon fordrer, i et bemærkelsesværdigt forhold til den systematiske arbejdsdeling, som grundlæggerne af det 18. århundredes klassiske økonomi støttede - og som Marx kritiserede - derved, at forbindelsen synes at korrigere Karl Poppers typologi fra The Open Society and Its Enemies (1944/45) på et bestemt punkt. Nemlig at der fra det såkaldt lukkede samfunds mest prominente fortaler, hvem jo hos Popper er Platon, går en lige linie til det åbne, liberale samfunds økonomiske arbejdsdeling, hvis "frivillighed" og "spontane orden" altså bestemt lader sig diskutere. Overhovedet kan modsætningsparret triangulær vs. polær/holistisk magt for mig at se bedre bruges til at beskrive moderne politiske systemer efter den borgerlige teoris begyndelse med naturrettens Thomas Hobbes og John Locke, hvem netop Rousseau reagerede på med $\sin D u$ Contrat Social (1762).

På en såvel kronologisk som tematisk linie stipulerer Platon og Marx yderpunkterne i utopiens historie med More som vægtigt intermezzo. Førstnævnte havde den hierakiske bystat som utopi, mens Marx satte sin lid til videnskaben og forkastede idealismen, og mellem disse poler gav Mores humanistisk-politiske engagement nye drømme indhold. Fra Platon til sidstnævnte passerer knap 2000 år revy. Det kan synes vel flot at affeje hele 
denne periodes utopitænkning som gamle fantasier af teologisk art, men alle middelalderens religiøse utopier var netop predeterminerede og ikke menneskeligt skabte. Vigtigt resterer der dog at indskyde, at kristenheden beredte Europa på den lighedstanke, der senere skulle blive så central i naturretten og siden i de demokratiske bevægelser, selvom kristenhedens lighed rummede en lighed $\mathrm{i}$ uværdighed qua den kristne syndsbevidsthed, mens eftertidens lighed lå i menneskenes lige værdighed. Blot var det først med renæssancens almene verdsliggørelse, at utopien kunne blive utopi og Europa kunne blive europæisk.

\section{III}

„Europe, your name is frailty“, siger Edgar Morin i sin personlige, men ligeledes forsigtige bog Penser l'Europe (1987) om europæisk kultur, hvis sjæl ifølge forfatteren slet ikke findes, men altid forandres og lever gennem vekselvirkende modsætningspar som fornuft/følelse, evolution/revolution, krig/fred o.lign. ganske som i mit åbningscitat. Med ovenstående har jeg imidlertid vovet den definition eller det koncentrat, at Europa simpelthen er en drøm, ja hun er det stof, drømme er gjort af, sådan som Shakespeare formulerede sig med hele renæssancens vægt i romancen- The Tempest fra 1611. Verden er ufuldkommen, men i drømmen søger mennesket den sublimt elementære mening bagved, skønt den eventuelt viser sig at være tragisk. Europa er en sådan menneskelig stræben.

Jeg har fremhævet, hvorledes Europa fødtes sammen med det humanistiske ideal om den bedste verden for menneskene, og jeg har undersøgt rastløshedens dimensioner hos More, Platon og Marx. Den naturlige fortsættelse indfries efter min forvisning alene gennem en fornyet respekt for utopien, for uden den bliver Europa ueuropæisk, dvs. forfalden til kølig eller varmblodet accept af det givne, som var det faldet ned fra himlen. Min holdning placerer sig således i diskussionen om, hvorvidt utopien pr. definition er umulig eller mulig. Popper tog parti for det sidste vèd i tråd med den af Lasky benævnte "engelske ideologi“ og konservatismen fra Burke at advare imod utopier som sådan; Hannah Arendt refererede et lignende synspunkt i selve mottoet 
til sit store opus om totalitarismens oprindelse med sætningen om normale menneskers forglemmelse af, at alt er muligt. Og hele den anti-utopiske romangenre fra Aldous Huxley, Arthur Koestler og George Orwell begrunder sig på samme standpunkt: det sterile, monolitiske og menneskefjendske helvede udgør en sandsynlig følge af visse politiske ideologier. Trods min ublandede anerkendelse af disse dystopier må der skelnes for at dette essay ikke afrundes med en trivialisering af det fænomen, det handler om. En utopi giver kun logisk mening som noget umuligt, mens utopien nok kan efterstræbes på et praktisk plan. Det, der lader sig realisere, er derfor højst et billede af en utopi, aldrig den selv, for den vedbliver at være troldsplinten i vore øjne, vedbliver med at fortrylle og forføre os, irritere og inspirere, gøde og forpeste, det ene og det andet, om vi altså tør holde øjnene åbne. Men hvis modet svigter, så bliver vi med sikkerhed det, grækerne sagde om de folk, der beboede det Europa mod nord, de vendte ryggen til. Barbarer.

\section{Note}

Jeg minder om, at der overalt i teksten er forudsat et "Vest-" foran ordene Europa og europæisk. Mere gør jeg ikke krav på. 
